Terbit online pada laman web jurnal : http://e-journal.sastra-unes.com/index.php/JIPS

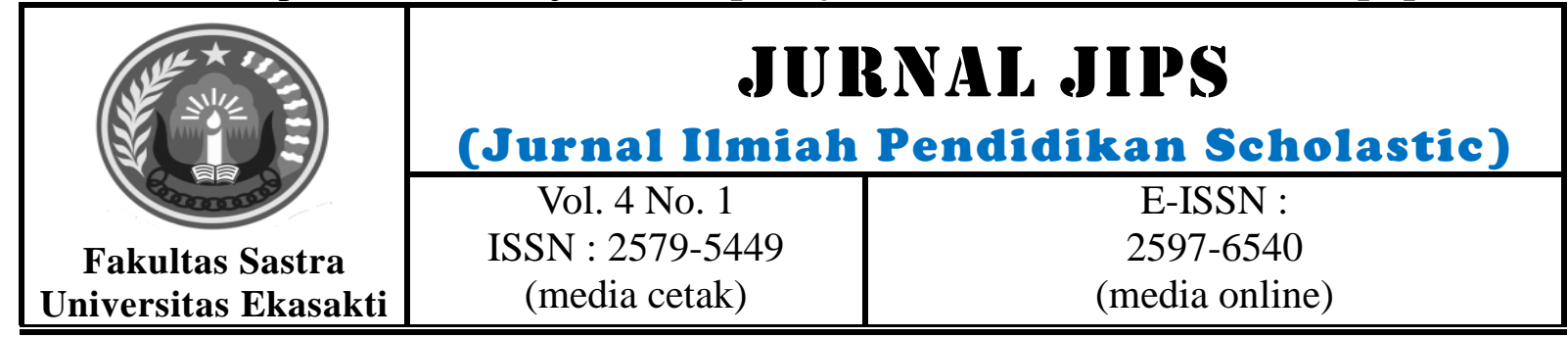

\title{
THE EFFECT OF CONVENTIONAL STRATEGY TOWARD READING COMPREHENSION OF NARRATIVE TEXT AT ELEVENTH GRADE SOCIAL SCIENCE OF SMA NEGERI 1 TALAMAU PASAMAN BARAT
}

\author{
Yessy Marzona \\ Universitas Ekasakti \\ yessy.marzona@gmail.com
}

\begin{abstract}
In teaching reading comprehension, teaching strategy influence students' reading comprehension. Strategy which was used in this experimental research was conventional strategy. Conventional strategy can be used as teaching strategy in teaching reading comprehension. The purpose of this research was to find out whether the students who are taught by conventional strategy have better reading comprehension of narrative text than those who are not taught by conventional strategy. This research was an experimental research with factorial design $2 x 2$. It was conducted at SMA Negeri 1 Talamau Pasaman Barat. The population of this research was eleventh grade social science students with total population of 40 students. The sample was taken by using total sampling; so all of population was taken as sample. XI IPS 2 was experimental class and XI IPS 1 as control class. The instruments of this research were reading comprehension test and questionnaire. The data was analyzed by two ways ANOVA (ANOVA 2x2). The results of this research are (1) Reading comprehension of students who are taught by conventional strategy is not better than reading comprehension of students who are not taught by conventional strategy. $F o=196.582>F t=2.69$, it means that Ha is rejected.
\end{abstract}

Keywords: Conventional Strategy, Reading Comprehension, Narrative Text

(C) 2020Jurnal JIPS

\section{INTRODUCTION}

Reading comprehension also helps the students to understand a text detail. Conventional strategy is the way of teaching English that is used by teacher in taching English. "The teachers arrange the questions in the classroom, to make the questions which is given to the students be effective, it is important to apply questioning stage which can assist students to engage actively with the text through posing and answering questions process" (Galda \& Graves, 2003:44). In addition, Lowry and Cormier (1999) state "there are three placements of questions: prereading, during reading, and after reading". The process is elaborated in the following paragraph.

Pre- reading questions are questions that are given before the passage is read. In this process, the teachers often use questions to activate prior knowledge of students which aimed to make them involve in material that will be discussed later. In this phase, the teachers should make the students be able to predict and connect to the text based on what they already know. 
Therefore, if a teacher wants the students to focus only on the very specific parts of the text or want to assist them in understanding the text, prereading will serve that purpose.

During-reading questions are questions that are given while the students are reading the given topic. During- questions usually pose explicit and implicit textual information of a text. The teachers guide and monitor the interaction between the students and the text, which allows the students to arrange new vocabulary, important information's and details, to summarize information's, and to record reactions and opinions. Questions supplied in this stage tend to focus on the students' attention and to improve their abilities to answer the post reading questions. Moreover, most of questioning interaction occurs in this process.

In the after- reading questions part, the students are engaged to any types of questions which is aimed to know or check the students' understanding on what they have read. As Abbot, et.al (1981:101) states that activities in the post reading stage are a kind of follow- up activity. In this phase, the teacher usually reviews the lesson which has been taught. Besides teachers should also focus on the value of questions that the value may depend on the level of the questions as well as the quality of the students' response and participation. Conventional teaching reading comprehension focus on teacher oriented only. It is a model of teaching reading based on the traditional perspective that is the teachercentered model. It means that students to be passive and teacher to be active in the reading class room.

According to the curriculum 2006, in the standard competency of senior high school, exposition and narrative are considered as the most important ones to be taught to high school. In this case, the researcher chooses narrative text because it is also offered in the curriculum for second semester at grade XI. After having preliminary research at Grade XI students of SMA Negeri 1 Talamau on July $19^{\text {th }} 2018$, the researcher found that the English achievement was low. It was found $3.6 \%$ students of Grade XI 1 got 60-69 point, and $2.16 \%$ got $70-79$ point, $2.16 \%$ students of Grade XI 2 got 60- 69 point and $1.44 \%$ got $70-79$ point. It was proved by KKM (Minimum Achievement Criteria). The perfect score is 100 while the minimum of KKM is 75 .

Based on the data above and the interview of the English teacher, according to English teacher the problem was in reading comprehension of the text. Because most of question found in English examination was reading. Based on the background of the problem above the researcher identified some problems faced by students in reading comprehension. The problems came from both sides; First, the students got difficulties to comprehend the text. The researcher limited the problem to the strategy used in teaching reading that influence their reading comprehension of narrative text. So this research was limited on the effect of conventional strategy and toward reading comprehension of narrative text at the eleventh grade social science of SMA Negeri 1 Talamau. The problem of the research can be formulated as follows: Do the students who are taught by conventional strategy get better result in reading comprehension of narrative text than those students who are not taught by conventional strategy at grade XI social science of SMA Negeri 1 Talamau

\section{RESEARCH METHOD}

This research was quasi- experimental research. The researcher used two classes. They were experimental class by using conventional strategy and control class by did not use conventional strategy. Both classes had the same material, length of time and the same teacher. This research only used post- test toward the two groups (experimental and control group). There was no pretest given to either group (control and experiment group) in order to control the simple testing effect and interaction between testing and treatment. In the process of teaching, the differences between experimental class and control class were only in the strategy used. The material and the time allocated for two classes were the same. This research was used treatment factorial design by block $(2 \times 2)$ design which shows the effect of the variables. This research was done at SMA Negeri 1 Talamau Pasaman Barat. The population of this research was the

Jurnal JIPS (Jurnal Ilmiah Pendidikan Scholastic ) Vol. 4 No. 1 (2019) ISSN : 2579-5449

This work is licensed under a Creative Commons Attribution-NonCommercial 4.0 International License. 
eleventh grade social science students of SMA Negeri 1 Talamau. There were 40 students who were divided into two classes; they were XI IPS
1 and XI IPS 2. The sample of this research was selected by total sampling. By using this technique the existing class was taken.

\section{RESULTS AND DISCUSSION}

Based on the hypothesis that conventional strategy was better than are not taught by conventional strategy to students' reading comprehension

\section{Hypothesis}

Ho: The students who are taught by using conventional strategy do not have better reading comprehension than those who are not taught by conventional strategy.

$H a$ : The students who are taught by using conventional strategy have better reading comprehension than those who are not taught by conventional strategy.

The result of reading comprehension test for both of experimental class and control class could be seen at Table 1 below.

\section{CONCLUSION}

accepted and Ho is rejected. It means that the students who are taught by conventional strategy has better reading comprehension that who are not taught by conventional strategy. The statistic can be seen in appendix 25 page 208 . From the result of first hypothesis, it could be seen that the mean score of experimental class which was taught by conventional strategy was higher than control class which was not taught by

conventional strategy. It can be concluded that conventional strategy gave significant effect toward students' reading comprehension. This finding was in line with the findings of research which was conducted by Dian Pramesti (2014). She found that the students' physic thinking that were taught by strategy learning by conventional was better than are not taught by conventional teaching.

\begin{tabular}{|c|c|c|c|}
\hline $\begin{array}{c}\text { Str } \\
\text { ategy }\end{array}$ & $o^{F}$ & $t^{\mathrm{I}}$ & te \\
\hline $\begin{array}{c}\text { Con } \\
\text { ventional } \\
\text { strat } \\
\text { egy }\end{array}$ & $\begin{array}{r}96.5 \\
82\end{array}$ & $.69^{2}$ & $\begin{array}{r}\text { Fo } \\
\text { bserved }> \\
\text { Ftable } \\
\text { Ha: } \\
\text { accepted }\end{array}$ \\
\hline
\end{tabular}

From the table above, itmeans that $\mathrm{Ha}$ can be concluded that $\mathrm{F}_{\text {observed }}$ is 


\section{Bibliography}

[1]Brown,

H. Douglas. 2001.

Teaching by

Principles: An

Interactive Approach

language Pedagogy. $2^{\text {nd }}$ eds. New York: Addison Wesley Longman, Inc.

[2]Cain, K.E, Bryant, P.E \& Oakhill, J. 2004. Children's Reading Comprehension Ability: Concurrent Prediction by Working Memory, Verbal Ability and component skills. Journal of educational psychology 2004, vol 96. Retrieved from http://www.psych.lancs.ac.uk/people/uploa ds/KateCain20050929TI05101.pdf.

[3]Retrieved on 25 January 2011

[4]Gay, L.R, \& Airasian, Peter. 2000. Educational Research: Competencies for Analysis and Application ( $\left.6^{\text {th }} e d\right)$. New Jersey: Pearson Education, Inc.

[5]McWhorter, K. T. 1986. Answer Key and to Instructor's Manual to Accompany Guide to College Reading. New York: Little Brown.

[6]Nuttal, Christine. 1992.

Teaching Reading Skills in

Foreign Language. London:

[7]Heinemann Educational Books.

[8]Suetomo. 1993. Dasar- dasar Interaksi Belajar Dan Mengajar. Surabaya: Usaha Nasional.

Ur, Penny.2000. A Course in Language

Teaching: Practice and Theory. Cambridge:Cambridge University Press. 